\title{
Effect of different plant spacing on the performance of radish in the agro- climatic conditions of Swabi
}

\author{
Adil Khan ${ }^{1}$, Ibad Ullah Jan², Muhammad Ali ${ }^{3 *}$, Muhammad Muzammil \\ Jahangir $^{1}$, Waqar Karim ${ }^{1}$, Asif Ali Khan ${ }^{1}$, Misbah Ullah ${ }^{4}$ and \\ Muhammad Zeshan Rafique ${ }^{1}$ \\ 1. Institute of Horticultural Sciences, University of Agriculture, Faisalabad-Pakistan \\ 2. Department of Agriculture, The University of Swabi-Pakistan \\ 3. College of Horticulture, Northwest A\&F University, Yangling 712100 Shaanxi-China \\ 4. College of Plant Protection, Northwest A\&F University Yangling-712100 Shaanxi-China \\ *Corresponding author's email: alinhorti@yahoo.com \\ Citation \\ Adil Khan, Ibad Ullah Jan, Muhammad Ali, Muhammad Muzammil Jahangir, Waqar Karim, Asif Ali Khan, Misbah \\ Ullah and Muhammad Zeshan Rafique. Effect of different plant spacing on the performance of radish in the agro- \\ climatic conditions of Swabi. Pure and Applied Biology. Vol. 5, Issue 4, pp1120-1125. \\ http://dx.doi.org/10.19045/bspab.2016.50134
}

\begin{tabular}{llll}
\hline \hline Received: 17/06/2016 & Revised: 03/10/2016 & Accepted: 07/10/2016 & Online First: 22/10/2016 \\
\hline \hline
\end{tabular}

\section{Abstract}

To study the effect of different spacing on the performance of radish under the agro-climatic conditions of Swabi, a trial was carried out at Agricultural Farm, The University of Swabi, Pakistan. Radish seeds were sown at different plant spacing of 6 (control), 12 and 18 centimeter (cm). The experiment was laid out in Randomized Complete Block (RCB) Design with three replications. There was a significant effect of plant-to-plant spacing on number of leaves, petiole width $(\mathrm{cm})$, leaf blade width $(\mathrm{cm})$, petiole length, root weight plant $^{-1}$, root width (mid), biomass and root length. Maximum number of leaves (41.66), petiole width (1.34), leaf blade width (17.38), petiole length (4.16), root weight plant $^{-1}(1625 \mathrm{gm})$, root length $(43.36 \mathrm{~cm})$ root width (mid) $(7.34 \mathrm{~cm})$ and biomass $(1726 \mathrm{~g})$ were recorded in plants with spacing of $18 \mathrm{~cm}$, while minimum number of leaves (29.31), petiole width $(0.68)$, leaf blade width $(12.35 \mathrm{~cm})$, petiole length $(2.7 \mathrm{~cm})$, root weight plant ${ }^{-1}(810.3 \mathrm{gm})$ root length $(31.75 \mathrm{~cm})$ root width $(\mathrm{mid})(5.10 \mathrm{~cm})$ and biomass $(1076 \mathrm{~g}$ ) were recorded in plants with plant-to-plant distance of $6 \mathrm{~cm}$. Based on the results, it is recommended that plant spacing of $18 \mathrm{~cm}$ should be kept for optimum growth and maximum production of radish in agro-climatic conditions of Swabi region.

Keywords: Raphanus sativus; Radish; Root weight; Spacing; Swabi; Yield

\section{Introduction}

Radish cultivated by the vegetable growers in Pakistan is quite low in quality and yield. Higher yield in radish crop depends upon cultural practices on which proper application of fertilizers and plant populations have found to contribute greatly
[1]. Radish is fast-maturing, easy-to-grow root vegetable in both tropical and temperate regions [2]. Radish are mainly used as an edible root and leafy vegetable, which are rich in minerals, energy, carbohydrates, fibers, protein and vitamin $\mathrm{A}, \mathrm{C}, \mathrm{E}$ and $\mathrm{K}$ [3]. The large-rooted oriental type radish 
requires 45-100 days, according to cultivar. Chinese half-long grown in Hawaii, matures in 40-45days, but under similar conditions, Japanese long type requires $70-80$ days. The edible portion consists largely of pectin and proto pectin. About $100 \mathrm{~g}$ of edible radish consist of 1.0 milligram $(\mathrm{mg})$ of protein 94 $\mathrm{mg}$ of water $0.7 \mathrm{mg}$ of fiber, $4.0 \mathrm{mg}$ of carbohydrates $0.1 \mathrm{mg}$ of fat, $42 \mathrm{mg}$ of calcium and $1 \mathrm{mg}$ of iron. Edible root is rich in carbohydrates and protein [4]. Many factors that are responsible for low yield and quality of specific vegetables include fertilizer application, cultural practices, soil type, sowing method, cultural practices etc. Higher yield in radish crop depend upon cultural practices on which proper application of fertilizers and plant population have been found to contribute greatly [5]. One of the factors responsible for reduced growth and lower yield of vegetables is cultural practices, time of sowing and spacing. However, the suitable time of sowing varies with the locality [6]. In Khyber Pakhtunkhwa, different cultivars of radishes are grown including some popular cultivars like green neck and lalpari. A minor increase has noticed in the yield of radish $\left(15.57 \mathrm{t} \mathrm{ha}^{-1}\right.$ in $2004-05 \& 15.91 \mathrm{t} \mathrm{ha}^{-1}$ in 2005-06). However, it is too much low as compared to the production of other agricultural countries. The population of plant affect the growth and yield of vegetables; Optimum spacing of a radish seed crop is a debated topic. In case of spacing the yield is poor due to the population proper distances between crops are very necessary because the yield is greatly affected by the spacing [7]. Yield of any crop can be increases up to substantial quantity by using improved varieties and modern technologies, improved production techniques and proper management. Radish is one of the most marketable winter vegetable. The roots are eaten raw, cooked, or preserved by storage, pickling, canning, or drying $[8,9]$. Radish is not only used for edible purposes but it also has certain medicinal uses helps in preventing liver trouble, piles, jaundice, constipation increase appetite and cooling effect.

The wider row spacing may be preferred, as this will increase airflow through the crop, reducing disease pressures [10]. This allows the plant to reach much of its seed bearing potential for maximum yields per plant in the field. The rapid increase in root girth and weight of radish are due to vigorous vegetative growth in the early planting stage, results in more photosynthetic translocation from leaves to roots. Among different plant spacing, wider spacing showed significantly higher values for root girth and root weight [11]. Root girth, weight and other reproductive processes are negative affected as the plant density increases, might cause competition for light, moisture and nutrients. The wider spacing provided more chance for development of root by proper utilization of assimilate which resulted in a maximum root girth and weight [12]. The present investigation was taken-up to determine the optimum spacing in order to have maximum vegetative growth and higher yields of radish.

\section{Materials and methods}

The present experiment entitled "Effect of different spacing on the performance of radish in the agro-climatic conditions of Swabi" conducted at Agricultural Farm, The University of Swabi, Pakistan, during the cropping season of 2014. The experiment was carried out at Randomized Complete Block (RCB) Design with three replications. Radish seed of cultivar 'Green Neck' was sown at different plant-to-plant spacing i.e.6, 12 and $18 \mathrm{~cm}$ while row to row distance was kept constant at 2 feet. The recommended cultural practices including weeding, fertilization, hoeing etc. were done in order to ensure optimum growth and yield of 
radish. Data were recorded from the following parameters:

\section{Number of leaves}

Total number of leaves was counted from 15 selective plants in three replications.

\section{Leaf length [cm]:}

Measure largest leaf including petiole with the help of inch tape.

\section{Leaf blade width}

Leaf blade width was measured through measuring tape. Measure the widest part of leaf.

\section{Petiole length}

Measured where blade intercept with petiole. Petiole length was measured through measuring tape.

\section{Petiole width [cm]}

Measure widest point of wide leaf and measure midrib width when blade extend to the axis.

\section{Root weight plant ${ }^{-1}$}

Data regarding Root weight per plant was calculated through electric balance. Root weight was done at selected plant.

\section{Root length}

Root length was calculated through measuring tape from three replications of fifteen plants.

\section{Root width middle [cm]:}

Measure the width at middle with the help of vernier calliper.

\section{Biomass [g]:}

Biomass was measure when whole plant was uprooted (the leaves are attached with the root) with the help of digital balance.

\section{Data analysis}

The data were analysed statistically using Statistics 8.1 software, ANOVA and least significant difference (LSD) techniques were applied in order to see any difference among the plant to plant spacing.

\section{Results and discussion}

\section{Number of leaves}

The mean values concerning number of leaves are given in Table 1 and mean of square are presented in Table 2 which shows a highly significant effect on plant-to-plant spacing. Upper limit numbers of leaves are (41.66) calculated in plants having space of $18 \mathrm{~cm}$ while, the lowest number of leaves are (29.31) observed in plants having space of $6 \mathrm{~cm}$. same results are confirmed by the findings of Shrivastava that as we increase the spacing between two plants, there will be a significant increase occur in number of leaves [13].

\section{Leaf length $(\mathrm{cm})$}

The mean values regarding leaf length is given in Table 1, whereas mean of square in Table 2. The mean table shows that plant to plant spacing significantly affected the leaf length of radish. The maximum leaf length $(40.77 \mathrm{~cm})$ was recorded in plants having plant to plant distance of $18 \mathrm{~cm}$. while minimum leaf length $(32.29 \mathrm{~cm})$ was observed in plants with plant to plant spacing of $6 \mathrm{~cm}$. Pervez and Gormade, also reported similar results that maximum leaf length is obtained from high plant to plant spacing $[7,9]$.

\section{Leaf blade width}

Table 1 show mean values pertaining leaf blade width and mean square values are given in Table 2 . The table shows that there is a significant change in leaf blade width in relation with plant-to-plant spacing. The maximum value obtained from leaf blade width is (17.38) on $18 \mathrm{~cm}$ spacing, whereas the minimum value observed is (12.35) on 6 $\mathrm{cm}$ space. Ahmad and Chatterjee give the same result that increasing plant-to-plant space give us a significant result $[10,14]$.

\section{Petiole length}

The mean values dependable on petiole length are given in Table 1 and mean square in Table 2. The data shows significant value regarding petiole length that it is affected by plant-to-plant spacing. The maximum value in contrast with petiole length is (4.15) on $18 \mathrm{~cm}$, while the minimum value is $(2.72 \mathrm{~cm})$ on $6 \mathrm{~cm}$ plant distance. Sharma, determine the same result as above [11]. 


\section{Petiole width}

Mean values reliable for petiole width are given in Table 1 and mean square values is presented in Table 2. The data shows significant result of plant-to-plant spacing regarding the petiole width. The highest value obtained regarding the petiole width is $(1.34 \mathrm{~cm})$ whereas the lowest petiole width obtained is $(0.67 \mathrm{~cm})$. Our result shows similarity with findings of Miami [15].

\section{Root weight plant ${ }^{-1}$}

The data pertaining mean values of attribute root weight plant ${ }^{-1}$ is given in Table 1 and ANOVA mean square in Table 2. The on hand table portray a significant value in judgment with root weight plant $^{-1}$. The greatest value in association with root weight per plant ${ }^{-1}$ is $(1625 \mathrm{gm})$ in plant space of $18 \mathrm{~cm}$, whereas the smallest value in contrast with root weight per plant is $(810.3 \mathrm{gm})$ on plant spacing of $6 \mathrm{~cm}$. Our results in relation with root weight show link with the results of Sirkar and Ahmed that wider space help in improving root weight of radish $[8, \mathbf{1 0}]$.

\section{Root length}

The mean values related to root length are given in Table 1 and mean square values are presented in Table 2. The presented table expose significant value about root length. The maximum root length is $(43.36 \mathrm{~cm})$ on distance of $18 \mathrm{~cm}$, at the same time minimum root length is $(31.75 \mathrm{~cm})$ on $6 \mathrm{~cm}$. Minami and Sirkar reveal the same results regarding root length by increasing plant-toplant spacing a major increase in root length will occur $[8,15]$. The findings of Chatterjee and Som also have the similar result [14].

\section{Root width of middle (cm)}

The mean data of root width are given in Table 1 and ANOVA mean square values in Table 2. Data on root width (middle) of radish revealed significant difference in the plant-to-plant spacing of radish crop. The thickest root width (middle) $(7.34 \mathrm{~cm})$ was observed at the plants planted at spaced 18 $\mathrm{cm}$ and the thinnest root width (middle) $(5.10 \mathrm{~cm})$ recorded in the plants, planted at spaced of $6 \mathrm{~cm}$. These results are confirmed by the findings of Lenka and Kolota that maximum diameter of root recorded in the higher plant-to-plant spacing $[16,17]$.

\section{Biomass (g)}

Mean values data regarding biomass of radish in plant-to-plant spacing is presented in Table 1 and analysis of variance mean values in Table 2 . While statistical analysis of the data revealed a significant effect of plant-to-plant spacing on biomass of radish. However, the maximum biomass (1726 g) recorded plant sown at spacing of $18 \mathrm{~cm}$ and minimum biomass (1076 g) was recorded plant sown at spacing of $6 \mathrm{~cm}$. Our results are in conformity with the finding of Gormade and El-Desuki, who reported that high biomass is obtained with higher spacing $[9,18]$.

Table 1. Shows mean values of number of leaves, leaf length, leaf blade width, petiole length, petiole width, root length, root weight, root width and biomass

\begin{tabular}{|l|l|l|l|l|l|l|l|l|l|}
\hline $\begin{array}{l}\text { P×P spacing } \\
\text { feet) }\end{array}$ & $\begin{array}{l}\text { No. of } \\
\text { leaves }\end{array}$ & $\begin{array}{l}\text { Leaf } \\
\text { length }\end{array}$ & $\begin{array}{l}\text { Leaf } \\
\text { blade } \\
\text { width }\end{array}$ & $\begin{array}{l}\text { Petiole } \\
\text { length }\end{array}$ & $\begin{array}{l}\text { Petiole } \\
\text { width }\end{array}$ & $\begin{array}{l}\text { Root } \\
\text { weight } \\
\text { plant }^{-1}\end{array}$ & $\begin{array}{l}\text { Root } \\
\text { length }\end{array}$ & $\begin{array}{l}\text { Root } \\
\text { width } \\
\text { (mid) }\end{array}$ & Biomass \\
\hline 6 & $29.31 \mathrm{c}$ & $32.29 \mathrm{c}$ & $12.35 \mathrm{c}$ & $2.72 \mathrm{c}$ & $0.68 \mathrm{c}$ & $810.30 \mathrm{c}$ & $31.75 \mathrm{c}$ & $5.10 \mathrm{c}$ & $1076 \mathrm{c}$ \\
\hline 2 & $35.66 \mathrm{~b}$ & $35.53 \mathrm{~b}$ & $14.89 \mathrm{~b}$ & $3.78 \mathrm{~b}$ & $1.03 \mathrm{~b}$ & $1252.0 \mathrm{~b}$ & $35.82 \mathrm{~b}$ & $6.27 \mathrm{~b}$ & $1298 \mathrm{~b}$ \\
\hline 18 & $41.66 \mathrm{a}$ & $40.77 \mathrm{a}$ & $17.38 \mathrm{a}$ & $4.15 \mathrm{a}$ & $1.34 \mathrm{a}$ & $1625.0 \mathrm{a}$ & $43.36 \mathrm{a}$ & $7.34 \mathrm{a}$ & $1726 \mathrm{a}$ \\
\hline LSD (P $\leq \mathbf{0 . 0 5})$ & $\mathbf{0 . 6 3 7 4}$ & $\mathbf{2 . 7 8}$ & $\mathbf{1 5 3 . 9 2}$ & $\mathbf{0 . 0 3 3}$ & $\mathbf{0 . 0 4}$ & $\mathbf{1 5 3 . 9 2}$ & $\mathbf{2 . 3 5}$ & $\mathbf{2 . 7 8}$ & $\mathbf{2 . 7 8}$ \\
\hline
\end{tabular}


Table 2. Shows mean of square of different attributes

\begin{tabular}{|l|l|l|l|l|l|l|l|l|l|l|}
\hline S.O.V & D.F & $\begin{array}{l}\text { No. of } \\
\text { leaves }\end{array}$ & $\begin{array}{l}\text { Leaf } \\
\text { length }\end{array}$ & $\begin{array}{l}\text { Leaf } \\
\text { blade } \\
\text { width }\end{array}$ & $\begin{array}{l}\text { Petiole } \\
\text { length }\end{array}$ & $\begin{array}{l}\text { Petiole } \\
\text { width }\end{array}$ & $\begin{array}{l}\text { Root } \\
\text { weight } \\
\text { plant }\end{array}$ & $\begin{array}{l}\text { Root } \\
\text { length }\end{array}$ & $\begin{array}{l}\text { Root } \\
\text { width } \\
\text { (mid) }\end{array}$ & Biomass \\
\hline Replications & 2 & 10.003 & 2.70 & 4.9414 & 0.14530 & 0.03134 & 35411 & 9.291 & 0.79223 & 7500 \\
\hline Treatments & 2 & 114.42 & 54.97 & 18.9512 & 1.65643 & 0.33361 & 498940 & 104.104 & 0.64263 & 330988 \\
\hline Error & 4 & 0.079 & 0.81 & 0.1554 & 0.02063 & 0.00028 & 4610 & 1.083 & 0.54192 & 1938 \\
\hline CV\% & -- & $\mathbf{0 . 7 9}$ & $\mathbf{2 . 4 8}$ & $\mathbf{2 . 6 5}$ & $\mathbf{4 . 0 5}$ & $\mathbf{1 . 6 4}$ & $\mathbf{5 . 5 2}$ & $\mathbf{2 . 8 1}$ & $\mathbf{1 5 . 0 4}$ & $\mathbf{3 . 2 2}$ \\
\hline
\end{tabular}

\section{Conclusions}

The growth and yield parameters of different spacing show that spacing having significant effect on different attributes. Recommended space among plant-to-plant is very important for good quality and better yield of radish. Radish crop with planting distance of $18 \mathrm{~cm}$ gave maximum number of leaves (41.66), petiole width (1.34), leaf blade width (17.38), petiole length (4.15), root length $(43.36 \mathrm{~cm})$ root weight plant $^{-1}(1625 \mathrm{gm})$ root width $(7.34 \mathrm{~cm})$ and biomass $(1726 \mathrm{~g})$. Whereas, minimum number of leaves (29.30), petiole width (0.67), leaf blade width (12.35), petiole length (2.72), root length (31.75), root weight plant $^{-1}$ (810.3) root width (mid) $(5.10 \mathrm{~cm})$ and biomass $(1076 \mathrm{~g})$ have been observed in plants with spacing of $6 \mathrm{~cm}$.

\section{Authors' contributions}

Conceived and designed the experiments: IU Jan, Performed the experiments: A Khan \& AA Khan. Analyzed the data: M Ali, Contributed reagents/ materials/ analysis tools: MM Jahangir \& M Ullah, wrote the paper: W Karim, \& MZ Rafique.

\section{References}

1. Work P (1945). Vegetable Production and Marketing, pp: 381-2. John Wiley and Sons, Inc., London.

2. Alam M, Farooque AM, Nuruzzaman M \& Uddin J (2010). Effect of sowing time on growth and yield of three radish (Raphanus sativus L.) varieties. Bangladesh Res. Pub. J 3(3): 998-1006.

3. Gopalan C \& Balasubraminium (1996). Nutritive value of Indian food $\left(6^{\text {th }}\right.$ revised ed). KMR. New Delhi.
4. USDA (2016). Radish Selection, nutrition and storage. Produce for a Better Health Foundation.

5. Hussain I, Haq I, Sajid M \& Rehman A (1997). Effect of nitrogen alone and in combination with constant doses of potassium on yield of radish. Sarhad. J. Agric 13: 39-43.

6. Maurya AN, Pathak MP \& Singh KP (1990). A note on the effect of sowing dates, planting distances, steckling size on yield and quality of radish $C v$. Pusa Chetki Acta Hort 267: 169-173.

7. Pervez M, Ayub CM, Saleem BA, Virk NA \& Mahmood N (2004). Effect of nitrogen levels and spacing on growth and yield of radish (Raphanus sativus L.). Int. J. Agric. \& Biol. 6(3): 504506.

8. Sirkar B, Saha A \& Bose TK (1998). Effect of plant density on growth and yield of radish. J. Interacade 2(6): 1720.

9. Ghormade BG, Kale BP, Kulwal PP \& Deshmukh PP (1989). Seed production studies in some verities of radish as influenced by date of stickling planting. P.K.U, Res. J 3 (1): 34-38.

10. Ahmad B, Bakhsh K, Hassan S \& Khokhar SB (2003). Economics of growing musk melon Faculty of Agricultural Economics and Rural Sociology, University of Agriculture, Faisalabad.

11. Sharma SK \& Kanavjia SP (1994). Influence of transplanting dates of stecklings and nitrogen levels on seed 
production of radish (Raphanus sativus L.). Seed Res 20: 92-95.

12. Hussain MM, Rehman MJ \& Uddain J (2008). Effect of Spacing on Growth and Yield of Radish (Raphanus sativus L.). J. Sher-e-bangla Agric. Univ 2(2): 65-69.

13. Shrivastava BK, Singh MP \& Jain SK (1992). Effect of spacing and nitrogen levels on growth, yield and quality of radish crop. Seed Res 20: 85-87.

14. Chattarjee R \& Som MG (1991). Response of Radish to various levels of nitrogen, potassium and plant spacing. Indian J. Hort. 48:145-7.

15. Minami K, Cordoso A, Costa F \& Duarte FR (1998). Effect of spacing on radish yield. department of Horticulture Escola superior de Agri 57: 169-73.

16. Kolota E \& Oriowski M (1984). Influence of the kind and rate of manure and mineral fertilization with nitrogen on the yield of horse radish. Szezecinic-Roinictwo-Seris-Agrotechniezna (Poland). 106: 61-70.4

17. Lenka PC, Dash PK, Das JN \& Das DK (1990). Effect of nitrogen and lime on growth and yield of carrot (Daucus Carota L.) Orissa J. Horti 8: 57-61.

18. El-Desuki M, Salman SR, El-Nemr \& Mawgoud AMR (2005). Effect of plant density and nitrogen application on growth, yield and quality of radish (Raphanus sativus L.) J. Agron 4(3): 225-229. 